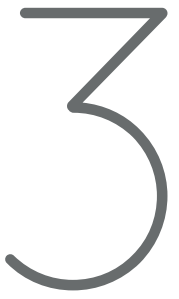

\title{
IN MEMORIAM DE HERNÁN MALO GONZÁLEZ
}

Simón Espinosa Cordero

I S Universidad Verdad, Núm. 1

Enero - Abril 1986, ISSN: 1390-28489 universidad 27 verdad 
En la mañana del día de su muerte, Hernán Malo trabajaba en el segundo tomo de su libro Pensamiento Universitario Ecuatoriano. Sobre su escritorio quedaban unas páginas borroneadas y un libro abierto: La Universidad Ultrajada, de Alfredo Pérez Guerrero.

No se escoge ni el día ni el modo de morir. No se escoge ni el día ni la hora de nacer. Se nos escoge el nacimiento desde fuera y se nos acumula la muerte desde adentro. Pero uno escoge, salvo en circunstancias de extrema miseria biológica, desnutrición y opresión social, el temple del vivir. Uno le da sentido a la propia vida y uno hace que la propia muerte sea luz que alumbre el pasado vivo u obscuridad que entenebrezca para siempre el pasado muerto.

Nada pues más apropiado en esta hora universitaria, en esta aula universitaria, ante profesores y estudiantes universitarios, que resumir la esencia del pensamiento de Hernán Malo sobre la universidad ecuatoriana. En la antigua Grecia los corredores se pasaban la tea olímpica en un relevo lleno de simbolismo. Recoger la antorcha del ideal universitario de manos de un hombre venerable, sostenerlo con el vigor de la juventud, hacerlo crecer con la fuerza de la razón, pasarlo a otras manos más nuevas y a otros espíritus más clarividentes es un homenaje práctico que le hubiera llenado de satisfacción a quien hizo el eje de su pensamiento de madurez, la lucha por una gran tesis: la Universidad, sede de la razón.

Resumiré pues, ciñéndome a las mismas palabras de Hernán Malo, lo más fielmente posible, esa gran tesis: 1. la universidad, institución perversa; 2. la esencia del concepto de Universidad; 3. las seis condiciones de la razón universitaria.

\section{La universidad, institución perversa}

Hernán Malo solía iniciar la defensa de su tesis de la Universidad, sede de la razón, atacando racionalmente un prejuicio secular, casi universal y muy nacional: el de la universidad como institución perversa.

Solía detenerse en el sentido de prejuicio o formulación emocional y subjetiva de vagos temores y pesimistas apreciaciones sobre la institución universitaria. 
Solía mostrar que estos prejuicios eran seculares y casi universales, desde la edad media hasta nuestros días, y en ellos, en países del primero, segundo, tercero y cuarto mundo.

Solía detenerse más ampliamente en los prejuicios ecuatorianos provenientes de múltiples sectores; de la universidad misma, de la prensa y otros medios, de padres de familia y sobre todo de los grupos de represión política, económica, militar, religiosa y dogmática.

Expuestas las objeciones, acostumbraba proponer un primer ejercicio de razón, una especie de catarsis, una purificación del clima emocional. Atribuía la formación del prejuicio a dos fuerzas que se conjugaban: la estructuración social y económica de nuestro país que trataba de instrumentalizar la universidad como punta de lanza para la formación de élites académicas y tecnológicas en apariencia apolíticas y, en realidad, domesticadas, castradas y de talante herodiano o de agentes nacionales de la dependencia externa y de la continuación de un sistema socialmente injusto. Esta la una fuerza. La otra, el poder de la masa para elaborarse mitos, hallarse cabezas de turco, cabezas de nicaragüenses diríamos en estos días, en quienes descargar su agresividad nacida de los temores al cambio y a la con- ciencia de criticidad.

No negaba Hernán Malo la existencia de un conflicto y hasta de varios conflictos serios en la universidad ecuatoriana. Ni podía cerrar los ojos a sus deficiencias y limitaciones. Pero no las atribuía ni a la naturaleza de la universidad ni a la perversidad de sus profesores y estudiantes, sino a los mismos apretujones del subdesarrollo. En cuanto a la primera causa, la injusta estructuración económica y social, dejaba su análisis y probables caminos de comienzo de una solución a las diversas disciplinas universitarias, aplicando así uno de los postulados de su tesis: la mediatez de la razón práctica. En cuanto a la segunda causa: el tradicionalismo, agresividad y confusión de la masa, la destripaba valiéndose de instrumentos tomados de la antropología y sicología social.

\section{La esencia del concepto de la Universidad}

No me detendré en el segundo punto acerca de la esencia de la Universidad. Bastará indicar la predilección que Hernán Malo sentía por el concepto y la realidad de universidad en la Edad Media. La calificaba de "insuperable definición medieval". De ella deducía que la universidad es una comunidad igualitaria (ayuntamiento o conjunción) de maestros y estudiantes; que su objetivo sustancial no era imponer un dogma o una 
doctrina sino buscar la verdad (aprender los saberes); que ese aprender se proyecta a lo que hoy diríamos ciencias humanas y ciencias fisicomatemáticas, sin que, curiosamente, se haga mención al menos expresa de la Teología o sus adyacentes; que no hay duda de que elementos como la solidaridad, la defensa de los derechos de los menos favorecidos (los extranjeros, por ejemplo), la independencia para alcanzar la ciencia, no eran ficciones sino realidades que se dieron o al menos propugnaron en los albores de la universidad. Concluía Hernán Malo con esta consideración: "El hecho de que la universidad fuera desde su génesis, en notable dosis, un organismo de protección y defensa estudiantiles, con miras al saber en alguna forma autónomo, explica obviamente que haya nacido como una institución crítica en el sentido creador y a la vez problemático de la palabra".

No se agotaba aquí la reflexión de Hernán Malo sobre la esencia del concepto de Universidad, pero por la naturaleza de este acto sería inoportuno que me alargara más.

\section{Las seis condiciones de la razón universitaria.}

Indicaré rápidamente las seis condiciones propuestas por Hernán Malo sobre la universidad como sede o asiento y lugar propio de la razón.

1. La universidad tiene que ser sede de la autonomía de la razón. Para ello tiene en primera instancia que garantizar la libertad en su propio seno. La autonomía se ahoga con más frecuencia dentro de la universidad que desde fuera. La única norma válida para impedir una acción o actitud dentro de la universidad sería lo anti-racional o lo sub-racional de la misma. Malo entendía por sub-racional el proceso mental que parte de fórmulas, de afirmaciones elementalmente simplificadas, y la consigna fanática de orden religioso o político.

2. La universidad se debe a la verdad como compromiso de la razón. Esta es la grande y única limitación de la libertad que supone la autonomía. Aquí hay un aspecto ético y heroico del compromiso. Se dan formas de heroísmo. Todas ellas caben en la universidad. Hasta puede darse el sacrificio cruento cuando la obligación para con la razón crítica o para con la razón práctica vuelvan necesariamente político-activo el quehacer universitario, y con esto se suscite la reacción de las fuerzas que luchan por el poder. Surge entonces la imagen de Sócrates. 
3. El compromiso con la razón crítica es importante hoy. Aunque resulte incómodo para quienes preconizan un funcionamiento técnicamente mecanizado de la sociedad y aunque exista el peligro de la demagogia ligera so color de crítica, la universidad tiene que defender con celo su derecho a la crítica. Esta debe comenzar por la autocrítica universitaria. Su importancia no requiere ponderación. Es el acto político, un acto eminentemente universitario.

4. La razón dialéctica o dialogante significa el perpetuo diálogo entre quienes integran la universidad. Su empeño debe consistir en ser el modelo de diálogo en la razón y no en la exaltación emotiva. El diálogo en la universidad, entre las universidades y con la sociedad consuman la perfección de la razón dialéctica.

5. y 6. La razón práctica y la razón política debe ser entendidas como análisis de la realidad, como no encerramiento en el elitismo ni en torre alguna de marfil, pero tampoco como formas de praxis no universitarias que atentarían contra la misma razón práctica que debería ser análisis mediato y a fondo, si va a ser contribución realmente universitaria. Una universidad no política es a la postre una universidad no comprometida con la sociedad, y, al ser tal, es una universidad cercenada y carente de sentido para el hombre.

He aquí la esencia del pensamiento sobre la universidad como sede de la razón, propuesta por Hernán Malo. Pese a grandes obstáculos, pese a su poca resistencia sicológica, pese a sus grandes y humanísimos combates interiores, Malo luchó con denuedo y sacrificio por llevar este ideal a la práctica. El que con frecuencia no haya sido comprendido y con mayor frecuencia haya sido abandonado no son sino la contraprueba de su gran tesis y de su radical pasión por la universidad.

Dos rectores se han destacado nítidamente en este campo, sin negar méritos a lo ejecutado por los otros rectores. Hablo de esta Universidad. Aurelio Espinosa Pólit y Hernán Malo González. El uno luchó desde su tiempo histórico por consolidar una posición que había entrado en su crepúsculo. Algo de trágico hubo en su empeño. Pero mucho de heroico y grande. El otro luchó desde un tiempo histórico que comenzaba apenas a aurorar en los establecimientos católicos de nuestra patria. También el empeño de Malo tuvo visos de lo trágico. Pero lo trágico es el material con que se tejen los mejores sueños que siempre traen fecundos despertares. 
La Universidad Católica con justicia dedicó su biblioteca a la memoria de Aurelio Espinoza Pólit, maestro inolvidable. Con igual justicia dedica esta Aula Magna a Hernán Malo, inolvidable maestro. Qué mejor que esta aula, sede del debate universitario, lleve el nombre de quien hizo de la razón en sus múltiples formas la norma de todo debate, de todo diálogo, de todo encuentro intelectual, una razón que en él siempre estuvo iluminada por una luz interior, la acuciante, exigente y amorosa luz del corazón. 
